\title{
A fuzzy QFD methodology to improve logistics service
}

\author{
Siamak Noori ${ }^{a^{*}}$, Atefeh Zandagahi ${ }^{\mathrm{b}}$, Rosa Lali $^{\mathrm{b}}$ and Maryam Mostafavi ${ }^{\mathrm{c}}$
}

${ }^{a}$ Associate Professor, Department of Industrial Engineering, Iran University of Science and Technology, Tehran, Iran

${ }^{b}$ Master's Student, Department of Industrial Engineering, Iran University of Science and Technology, Tehran, Iran

'Master's in Industrial Engineering, Arak Branch, Islamic Azad University, Arak, Iran

\section{H R O N I C L E}

Article history:

Received October 15, 2012

Accepted January 24, 2014

Available online

March 62014

Keywords:

Customer service

Logistics service

Strategic management

Fuzzy QFD

House of quality

\begin{abstract}
A B S T R A C T
Customer service is increasingly being recognized as a source of competitive advantage. The keys to provide effective customer service are determining the customer needs, accurately, and meeting and exceeding the needs in a consistent manner. Companies should adapt a strategic, proactive focus on customer service based on understanding logistic processes and designing the logistics system to meet their needs. This paper proposes an approach based on the quality function deployment (QFD), for ranking strategic actions to improve logistics service. The paper addresses the issue of how to deploy the house of quality (HOQ) to effectively and efficiently improve logistics processes and thus customer satisfaction. For data collection, fuzzy logic is used to deal with the ill-defined nature of the qualitative linguistic judgments required in the proposed HOQ. The methodology has been tested by means of a real case application, which refers to an Iranian company operating in the manufacturing industry.
\end{abstract}

\section{Introduction}

Among leading firms, logistics has evolved over the past few years to the point where logistical competency is frequently viewed as a strategic resource (Mentzer et al., 1989). Properly exploited, logistical performance can help gain and retain profitable customers. Service quality enhancements have been proven to consistently result in an increased market share and revenue gains. Studies by Little (Shycon, 1992) indicate that the quality of a company's service may lead to gain or lose as much as 10 per cent in sales revenue. Service may well be the competitive arena of the future. According to (Chase \& Garvin, 1989) "Competition is shifting away from how companies build their products to how well they service customers before and after they build them. The manufacturers that thrive into the next generation, will compete by anticipating and responding to a truly comprehensive range of customer needs". Meeting customers' needs is the core objective of any firm, many of

* Corresponding author.

E-mail addresses: a.zandagahi@gmail.com (A. Zandagahi)

C 2014 Growing Science Ltd. All rights reserved doi: $10.5267 /$ j.ds1.2014.3.001 
today's most progressive and successful firms emphasize on logistics service as a competitive differentiator (Livingstone, 1992; Stern et al., 1993). These firms concentrate on creating or adding value for the customer.

Customer service represents the output of the logistics system and the place component of the firm's marketing mix. It is a measure of the effectiveness of the logistics system in creating time and place utility for a product (Lambert and Stock, 1993). A number of service elements are commonly related to logistics customer service, although the degree of importance attached to them differs from case to case depending on the specific customer needs (see e.g. LaLonde \& Zinszer, 1976; Sterling \& Lambert, 1987; Lambert \& Harrington, 1989; Sharma \& Lambert, 1991; Semeijn 1995). There is general agreement that excellent logistics customer service can be considered as a primary source of competitive advantage, and the keys to provide effective customer service are determining customer requirements accurately and responding to them in a consistent manner (e.g. Lambert \& Stock, 1993; Christopher, 1983; Fuller et al., 1993; Global Logistics Research Team). Therefore, logistics customer service planning ought to be carried out at the strategic level, and to be the most effective the planning process have to follow a systematic framework (Pirttilä \& Huiskonen, 1996).

Researchers have presented several planning frameworks (Lambert \& Stock, 1993; Christopher, 1983; Fuller et al., 1993; Byrne \& Markham, 1991), and they have similarities in what stages a comprehensive logistics customer service planning process have to include, and what analyses need to be performed. To manage logistics customer service as a strategic competitive weapon, three issues must be evaluated including customers' requirements, company's performance, and competitors' performance (Lambert \& Stock, 1993).

According to VanHuss (1993), there are some general agreements where excellent customer service can be considered as a source of competitive advantage for firms and the keys to provide effective customer service are determining customer needs accurately and meeting and exceeding the requirements in a consistent manner. O'Neil and Iveson (1991) defined the most cost-effective methods of providing required customer service levels as a part of logistics strategic management. Schary (1992) argued that customer service could become a dominant objective for logistics management in the 1990s. High levels of customer service have become a basic requirement for establishing and maintaining a presence in the market, and, although important, managing cost is secondary to service objectives. DeRoulet (1993) supported Schary by stating that instead of being just the other side of the cost trade-off, customer service is the primary key of a firm's marketing. In the competitive environment of today, each company should have a well-thought-out customer service strategy (Korpela et al., 1996).

In Section 2, we review the concept of customer service, customer service strategy, QFD and fuzzy QFD. In section 3, we describe the proposed methodology, and In Section 4, we demonstrate with a real example the use of the fuzzy QFD approach to support the strategic management process.

\section{Literature review}

\subsection{Customer service and customer service strategy}

The concept of customer service has gone through a profound evolution during the last decades. Before 1970, physical distribution was approached from a mechanistic and firm-oriented point of view, and satisfaction to customers was provided by creating time and place utility to the product (Manrodt \& Davis, 1992). In the 1970s and 1980s, customer service was still considered reactive and firm oriented while, in the late 1980s, the definition of customer service was changed towards the development of customer value (Manrodt \& Davis, 1992). Cooper et al. (1988) defined customer service as "a process for providing significant value-added benefits to the supply chain in a cost- 
effective way". Thus, the importance of customer service in creating value for the whole supply chain as well as for the end customer was recognized (Carothers, Adams, 1991; Langley, Holcomb).

Schary (1992) called for a strategic, proactive focus on customer service based on understanding logistic processes and designing the logistics system to meet their requirements. The objective was to create value for the customers. According to Manrodt and Davis (1992), the recent trends in customer service can be described as follows: (1) firms are becoming proactive in their method to customer service, and considerable attention is concentrated on how to provide the customer with valuecreating service before, during, and after the product is delivered, (2) the change is happening especially in response to aggressive customers who ask that suppliers take formal steps to detect the customer's requirements and to provide the desired value, (3) the key to providing breakthrough levels of customer service is to manage information flows effectively, (4) a shift to contractual-driven systems is happening, and (5) firms are under increasing pressure to generate value through enhanced customer service, and the firms with the necessary capabilities are evidencing an ability to reach sustainable competitive advantages (Korpela et al., 1996).

Besides, when speaking about service management, a dynamic perspective has to be adopted. Customer service is not a steady concept, but is continually in a state of change, and evolves through a continuous improvement cycle (Morris, 1996; Baines, 1996). Therefore, the quantitative measure of logistics performances delivered and expected has to be repeated over time, periodically monitoring gaps between expectations and perceptions. When a lack of correspondence happens, viable logistics areas and factors of intervention have to be detected, pondered and ranked in terms of efficiency and effectiveness. Since interventions imply expenditures, before taking steps toward implementation, a costs/benefits analysis is needed to undertake necessary actions starting from those factors with the highest effect on customer service. To conclude, providing logistics service, which meets customer expectations is a continuous process, which can be summarized in the following steps (Bottani \& Rizzi, 2005):

- understanding the customer's voice, that is requirements and expectations in terms of relevant logistics performances;

- evaluating customer's service perception;

- if a gap between perception and requirements happens, detecting viable steps implemented to improve customer satisfaction;

- identifying costs and benefits related to each step;

- implementing the most efficient actions for customer satisfaction by means of a cost/benefit analysis.

The quality function deployment (QFD) methodology has been found as a viable tool, which can be successfully implemented for this purpose (Akao, 1990). QFD is defined by the American Supplier Institute as "A system for translating consumer requirements into appropriate company requirements at each stage from research and product development to engineering and manufacturing to marketing/sales and distribution"' (Bottani \& Rizzi, 2005).

The QFD is a technique for product or service development, brand marketing, and product management (Celik et al., 2008). By concentrating on listening to the customers, QFD has been a successful tool to help a company's product development team systematically translate customer requirements (CRs) to appropriate product features. The success of QFD applications may be the result of some of its advantages, such as high customer satisfaction, greater customer focus, shorter lead time, development of cross-functional teamwork, and preservation of knowledge (Bossert, 1991; Eureka, 1987). 
A preliminary review of the literature has highlighted only few references where QFD has been associated with service assessment. Lapidus and Schibrowsky (1994) described the QFD applicability as a method for improving service starting from customer complaints. In their approach, customer complaints become the "whats" to be considered in the house of quality (HOQ). Conversely, we propose a proactive approach to be adopted before complaints occur: thus, "whats" do not emerge from complaints but from logistics and supply chain management literature.

Behara and Chase (1993) presented the QFD process in matching customer requirements to specific topic areas in service management. However, these applications do not provide a general tool to plan and to manage the trade-offs and correlations associated with customer requirements and firm viable actions. Stuart and Tax (1996) applied the QFD application to manage the service design phase. They recommended the implementation of HOQ as an effective tool to plan processes for a successful execution of services. Their approach is of general purpose and describes the general traits of a QFD method to design service strategies. However, the authors did not provide much detail on how the approach may be deployed for a practical in-field application. In conclusion, the works cited above deal with service management under a general perspective, and do not concentrate the approach on service performances which stem from logistics processes and activities.

Starting from the work of Bottani and Rizzi (2006), we develop a tool suitable to be adopted in the logistics and customer service. In addition, the primary objective is to introduce a methodology that could be directly adopted by practitioners in the logistics field. A cost/benefit analysis is also introduced to detect and to rank the most efficient steps towards improvement of logistics processes and customer satisfaction. A fuzzy approach is adopted since the methodology mainly relays on qualitative judgments given by panel of experts and by customers.

\subsection{QFD and fuzzy $Q F D$}

\subsection{1. $Q F D$}

The QFD, originated in 1972 in Japan, has been a successful tool to help the product design and development team systematically in translating market research and customer requirements into the technical requirements for product design. According to Bottani and Rizzi (2006), QFD is composed of four successive matrices: customer requirement planning matrix, product characteristics deployment matrix, process and quality control matrix, and operative instruction matrix. Here, the current research concentrates on the first matrix (customer requirement planning matrix). The customer requirement planning matrix, also known as "house of quality" (HOQ), is the first step in investigating customer needs and market requirements. HOQ begins with customer requirements (CRs) which are usually obtained from market survey or customer interview. The acquired CRs are translated into a list of measureable ECs. Based on the acquired CRs and ECs, the team can determine the relationships between CRs and ECs, the competitive analysis, and the correlations between ECs. The obtained information can be used to calculate the importance of ECs (Hauser \& Clausing, 1988). The components of HOQ are illustrated in Fig. 1. The fundamental rationale of HOQ is introduced in several publications (Cohen, 1995; Revelle et al., 1998).

\subsubsection{Fuzzy $Q F D$}

Fuzzy set theory, introduced by Zadeh (1965), was developed for solving problems in which descriptions of activities, observations, and judgments are subjective, vague, and imprecise (Liu, 2009). A number of scholars have applied the fuzzy set theory to QFD and developed various fuzzy QFD approaches. For instance, Khoo and Ho (1996) proposed the concept of fuzzy QFD and fuzzified linguistic variables to make them more reasonable. Besides, they also considered the correlations among CRs and the correlations among ECs. Chan et al. (1999) applied fuzzy number 
and entropy methods to derive the importance of CRs, respectively, and combined the results to obtain the final importance of CRs. Shen et al. (2001) found it necessary to translate customer requirements into trends of future analysis. They added a future tendency index to the importance of CRs to compute the final importance of CRs. Shen et al. (2001) mentioned that the importance ranking of ECs may be influenced by various factors, including types of fuzzy numbers, defuzzification methods, and the number of fuzzy numbers. It was found that defuzzification methods have relatively larger impact on the ranking result. Sohn and Choi (2001) applied fuzzy QFD to supply chain and included reliability in the assessment. They applied a fuzzy MCDM method to select a design with an optimal combination of reliability and customer satisfaction.

Chen et al. (2006) integrated fuzzy weighted average method and fuzzy expected value method to evaluate the importance of ECs. Bottani and Rizzi (2006) applied QFD in logistics and supply chain management. They translated linguistic values of customer requirements into fuzzy numbers and computed the importance of ECs using the conventional QFD method. Kahraman et al. (2006) employed the analytic network process (ANP) method to determine the importance of each EC and incorporated resource constraints, such as cost budget, to form a multi-objective programming problem and derived important ECs. Kwong et al. (2007) developed a fuzzy expert system approach to measure the importance of ECs and the correlations among ECs. These two measures were integrated to calculate the aggregated importance of ECs, etc. (Liu, 2010).

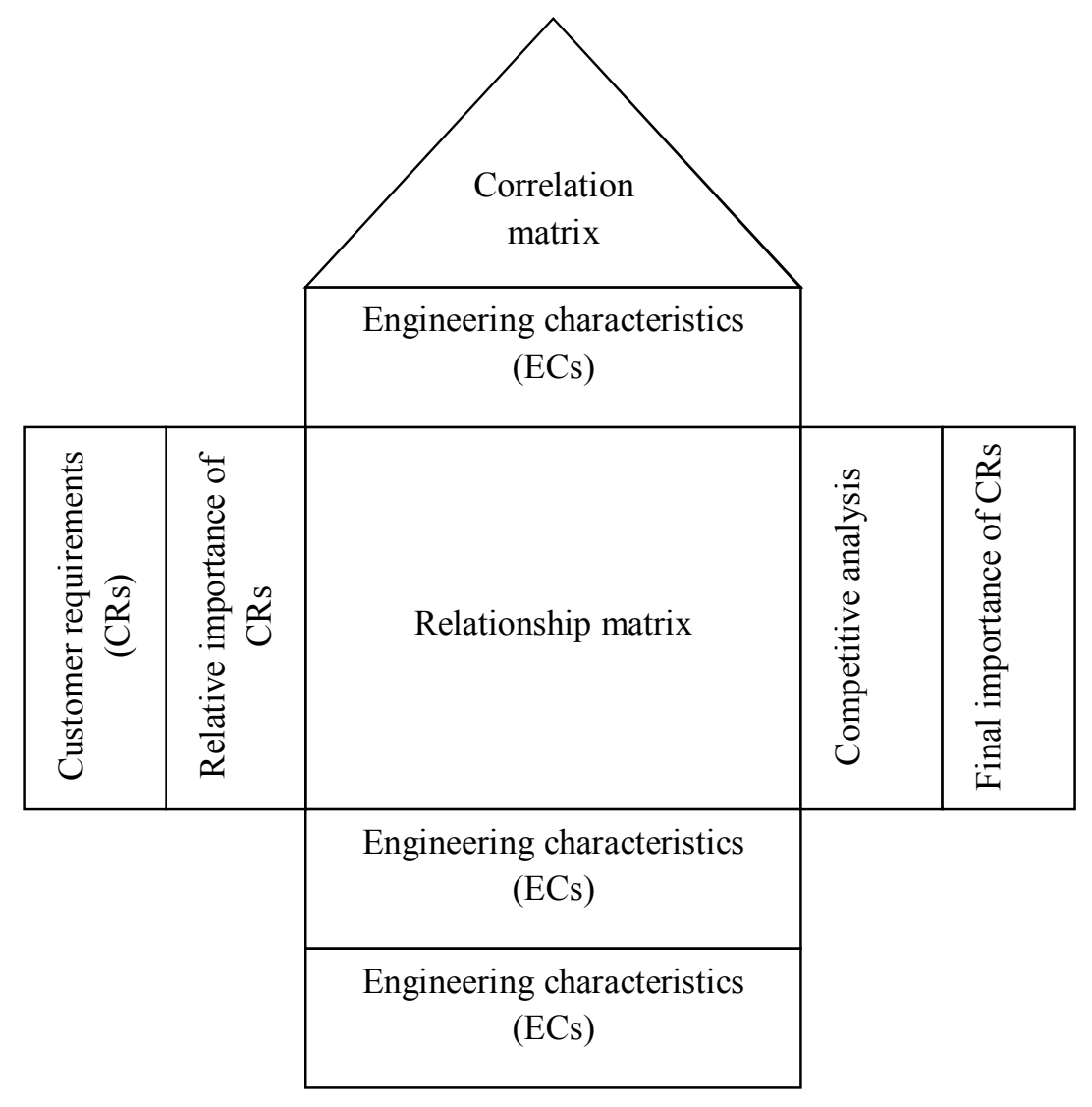

Fig. 1. Components of HOQ

\section{The proposed fuzzy QFD approach}

The methodology proposed is based on the translation of HOQ principles from product development field to logistics service management. While the traditional HOQ correlates customer requirements 
("whats") with engineering characteristics of new product under development ("hows"), in our approach customer service requirements in terms of logistics performances ("whats") are crossed over with viable strategic actions, either technical or managerial, that could be undertaken by the firm's top management to improve logistics processes ("'hows"). The related customer service HOQ is shown in Fig. 2.

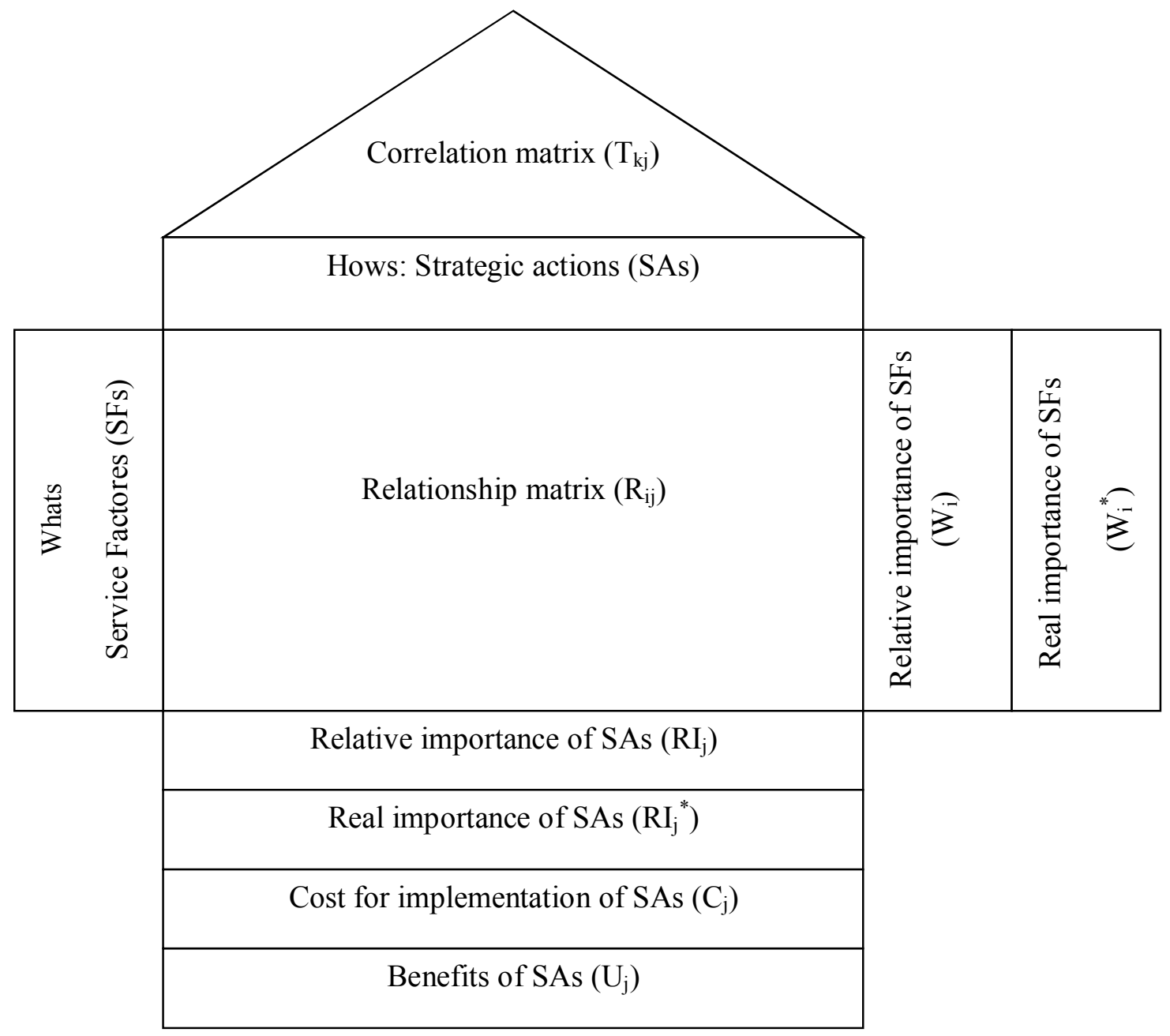

Fig. 2. The house of quality for the strategic management of logistics service (Bottani \& Rizzi, 2005)

As can be seen from the Fig. 2, "whats" elements express service factors SFi, $i=1 ; \ldots ; n$ affecting logistics service perception. These factors have been extensively described by logistics and supply chain management literature. The reader will find a comprehensive list of the main criteria that can be used for the evaluation of the logistics service in Franceschini and Rafele (2000). For the sake of clarity, the service factors proposed by the authors are shown in Table 1, together with a brief description.

\section{Table 1}

List of viable factors for the evaluation of logistics service, adapted from Franceschini and Rafele (2000)

\begin{tabular}{ll}
\hline Service factors "whats", & Description \\
\hline Lead-time & Time period elapsing from customer's order until receipt \\
Regularity & The dispersion around the mean value of the delivered lead-time \\
Reliability & Capability to deliver orders within the due date \\
Completeness & Capability to deliver full orders when required \\
Flexibility & Capability to modify orders in terms of due date and quantity when required \\
Correctness & Avoidance of mistakes in orders delivered \\
Harmfulness & Avoidance of damages in orders delivered \\
Productivity & Number of item produced in a given time period \\
\hline
\end{tabular}


Obviously, service factors listed in table do not give an absolute description of all viable factors that could be considered when perceived service has to be assessed. Depending on particular circumstances, factors could be either added or removed. Once customer service has been assessed, viable strategic actions $S A_{j}, j=1, \cdots, m$, the firm can undertake in the logistics field to improve service performances have to be identified and ranked in terms of both effectiveness and efficiency with regard to customer service improvement. Those actions correspond to "hows" in the proposed customer service HOQ. A list of possible "hows" when customer service performance related to logistics activities has to be improved is shown in Table 2. Again, Table 2 does not provide a definitive framework of all the options available, which depend on the particular circumstances.

The roof of correlations, the weights $W_{i}[n \times 1]$, the relationships matrix $R_{i j}[n \times m]$ and the relative importance of $\mathrm{SAs}$ vector $\mathrm{RI}_{\mathrm{j}}[1 \times \mathrm{m}]$ complete the HOQ. It is worth stressing that the weight vector, the correlations matrix and the relationships matrix translate linguistic judgments given by human beings. Therefore, an effective mean to deal with them would appear to be fuzzy logic.

\section{Table 2}

List of viable strategic actions (Bottani \& Rizzi, 2005)

\begin{tabular}{|c|c|}
\hline $\begin{array}{l}\text { Strategic actions } \\
\text { "hows", }\end{array}$ & Description \\
\hline $\begin{array}{l}\text { Just-In-Time } \\
\text { implementing }\end{array}$ & $\begin{array}{l}\text { T helps to streamline the logistics pipeline through the efficient flow of materials and information, i.e. by providing the } \\
\text { ght materials, in the right quantities and quality, in the right place at the right time. }\end{array}$ \\
\hline $\begin{array}{l}\text { Warehouse management } \\
\text { optimization }\end{array}$ & $\begin{array}{l}\text { The efficiency and the effectiveness of the logistics flows are deeply affected by optimized warehouse } \& \text { distribution centers } \\
\text { management policies. Shipping \& receiving, storage, picking activities can largely benefit from ad hoc optimization tools. }\end{array}$ \\
\hline $\begin{array}{l}\text { Transport } \\
\text { management }\end{array}$ & $\begin{array}{l}\text { Transportation has been recognized as a paramount factor affecting effectiveness and efficiency of logistics processes. } \\
\text { Through transportations, the product value is increased by making it available where and when it is required. However, } \\
\text { transports add significant costs, which could jeopardize the profitability of the supply chain. Therefore specific optimization } \\
\text { tools can be considered as viable actions to improve logistics performances perceived by customers. }\end{array}$ \\
\hline $\begin{array}{l}\text { Information } \\
\text { Technology }\end{array}$ & $\begin{array}{l}\text { Information technology is generic term used to include hardware, software and networking technologies, such as servers, } \\
\text { computer networks, expert systems, software for communication, such as Enterprise Requirement Planning (ERP), } \\
\text { Electronic Data Interchange (EDI), etc. All these tools play a significant role in synchronizing the flow of goods with the } \\
\text { flow of information, which affects the logistics performance of the supply chain. }\end{array}$ \\
\hline $\begin{array}{l}\text { Demand forecasting } \\
\text { Methods }\end{array}$ & $\begin{array}{l}\text { Accurate forecasting methods make it possible to match supply and demand, smoothing uncertainty, reducing safety stocks } \\
\text { and stock outs. The setup of collaborative programs, such as CPFR, VMI, or consignment aimed at reducing uncertainties } \\
\text { may be encompassed in this category. }\end{array}$ \\
\hline Other & epending on the particular circumstance, other strategic actions in the logistics field may be considered. \\
\hline
\end{tabular}

To well cope with vagueness of linguistics judgments required in building the HOQ, we propose to express importance weights, as well as relationships and correlations, with fuzzy triangular numbers. Thus, unless specified, all terms computed should be considered as fuzzy numbers. According to this premise, the importance weights $\mathrm{W}_{\mathrm{i}}$ is a fuzzy vector expressing the relative importance of SFs based on a defined fuzzy linguistic scale (Bottani, 2006). The reader may refer to Zadeh (1965), and Zimmermann (1991), for a complete description of fuzzy numbers and related algebra. In our approach, four new fuzzy elements have been added to the traditional HOQ, namely:

- the weighted importance of service factors;

- the weighted importance of strategic actions;

- the cost for the implementation of strategic actions;

- the marginal benefit of strategic actions.

These elements, as well as their role in ranking SAs, are detailed below.

\subsection{Weighted importance of service factors}

The weighted importance $\mathrm{W}_{\mathrm{i}}{ }^{*}$ of $\mathrm{SFs}$ is a $[\mathrm{n} \times 1]$ vector which expresses the real importance of each $\mathrm{SF}$. The introduction of $\mathrm{W}_{\mathrm{i}}^{*}$ is required to weight each service factor considering not only the importance the customer gives it, which is expressed by the value $\mathrm{W}_{\mathrm{i}}$, but also the performance delivered by the firm for that factor. To gain a competitive advantage, the firm must provide superior service to the customers on critical service factors, that is either those that are perceived as the most 
important ones or where service perceived is inferior. Conversely, improving service either for a factor whose importance is trivial or where the firm already delivers a superior service is useless. The weighted importance $\mathrm{W}_{\mathrm{i}}{ }^{*}$ is computed by assessing the distance $\mathrm{d}_{\mathrm{i}}$ between firm performance and that which is perceived by customers as superior, the latter being the performance that allows the firm to achieve customer satisfaction. Both the performance delivered and the target superior value could be retrieved from customer service surveys by asking the customer directly. Since both performance values are fuzzy, a distance between fuzzy numbers has to be assessed. To this extent, the Hamming procedure is suggested to be adopted (Chien \& Tsai, 2000). This procedure identifies the distance between two fuzzy numbers as the distance between the centers of gravity of the respective membership functions. From a mathematical point of view, given two fuzzy sets A and B, the Hamming distance $d\left(\mu_{A}(x), \mu_{B}(x)\right)$ between two fuzzy numbers belonging to A and B respectively, can be computed as:

$$
d\left(\mu_{A}(x), \mu_{B}(x)\right)=\int_{X}\left|\mu_{A}(x)-\mu_{B}(x)\right| d x,
$$

where $X$ is the universe of discourse. Due to the calculation method, the resulting Hamming distance is a crisp value. The $d_{i}$ parameters are then calculated according to Eq. (1). Then, the weighted importance $\mathrm{W}_{\mathrm{i}}{ }^{*}$ of SFs can be derived as follows:

$$
W_{i}^{*}=d_{i} \otimes W_{i}, \quad i=1, \ldots, m \text {. }
$$

\subsection{Weighted importance of strategic actions}

This element strives to determine which strategic action has the highest impact on customer satisfaction. It takes into account the weighted importance of service factors, the relationships matrix and the correlations matrix. As already detailed, the generic position $R_{i j}$ in the relationships matrix expresses the relationship between the $\mathrm{j}^{\text {th }} \mathrm{SA}$ with the $\mathrm{i}^{\text {th }} \mathrm{SF}$. Again, a fuzzy linguistic scale may be usefully adopted by DMs to interpret the vagueness and incomplete understanding of the relationships between "hows", and "whats". The importance $\mathrm{RI}_{\mathrm{j}}$ of each strategic action can then be calculated applying the following equation:

$$
R I_{j}=\sum_{i=1}^{n} W_{i}^{*} \otimes R_{i j}, \quad j=1, \ldots, m
$$

where $\mathrm{W}_{\mathrm{i}}{ }^{*}$ is the fuzzy weighted importance of $\mathrm{i}^{\text {th }}$ service factor, while $\mathrm{R}_{\mathrm{ij}}$ is the fuzzy number expressing the impact of the $\mathrm{j}^{\text {th }} \mathrm{SA}$ versus the ith $\mathrm{SF}$. In a similar manner, the generic position $\mathrm{T}_{\mathrm{kj}}, \mathrm{j}$, $\mathrm{k}=1, \ldots, \mathrm{m}, \mathrm{k} \neq \mathrm{j}$, in the correlations matrix expresses the correlation between the $\mathrm{k}^{\text {th }}$ and the $\mathrm{j}^{\mathrm{th}}$ " "hows". In order to quantitatively ponder the correlation between "hows", we adopt the approach of Tang et al. (2002). According to the authors, the correlation $\mathrm{T}_{\mathrm{kj}}$ can be interpreted as the incremental changes of the degree of attainment of the $\mathrm{j}^{\text {th }}$ " "how" when the attainment of the $\mathrm{k}^{\text {th }}$ one is unitary increased. Using this definition, the weighted importance $\mathrm{RI}_{\mathrm{j}}{ }^{*}$ can be computed as follows:

$$
R I_{j}^{*}=R I_{j} \otimes \sum_{k=j} T_{k j} \otimes R I_{k}, \quad j=1, \ldots, m
$$

\subsection{Cost and marginal benefit of strategic actions}

In order to complete the assessment and ranking of strategic actions, their cost of implementation should be considered. In this situation fuzzy logic becomes a fundamental tool in dealing with illdefined issues such as the evaluation of costs. While a DM may find objective difficulties in quantitatively assessing the costs of implementation of strategic actions, he/she can more easily give a judgment on a linguistic scale, ranging for instance from Very High to Very Low. This is why, in the lower part of the HOQ a fuzzy parameter $C_{j}$ has been added to ponder the cost of implementing the $\mathrm{j}^{\text {th }}$ strategic action. The marginal benefit $\mathrm{U}_{\mathrm{j}}$ of strategic actions can be calculated through the ratio between benefits and costs, as expressed by the following equation: 


$$
U_{j}=R I_{j}^{*} \otimes \frac{1}{C_{j}}, \quad j=1, \ldots, m
$$

Since both $\mathrm{RI}_{\mathrm{j}}{ }^{*}$ and $\mathrm{C}_{\mathrm{j}}$ parameters are fuzzy numbers, Eq. (5) describes an operation between fuzzy numbers; the resulting $U_{j}$ is thus a fuzzy number. In order to make SAs comparable and rank the results, defuzzified values should be computed. Due to its simplicity, the Yager method (Yager, 1981 ) is suggested as a viable tool to adopt in order to obtain final crisp marginal benefits. Starting from a fuzzy triangular number $a(l, m, u)$, the defuzzified value is computed as:

$$
\frac{l+2 m+u}{4}
$$

Once crisp values have been computed, SAs can be finally ranked. In particular, according to Trappey et al. (1996), the greater the crisp $U_{j}$ parameter, the higher the implementation priority of the corresponding strategic action. Strategic action which scores the highest is the one which has the highest impact on customer service, and therefore whose implementation should be considered by the firm top management to improve the logistics performance.

\section{Case study}

\subsection{The company}

In this section, the methodology developed is applied to a real industrial case, which refers to a major Iranian company operating in the manufacturing industry. HEPCO Company was established \& registered in March 1974, with the intention of assembly \& production of road construction equipment. In 1975 Hepco resumed operation in its premises in Arak consistory of 1000000 square meters of land \& 40000 square meters of production hall in collaboration with licencors; namely : International Harvester, Dynapac, Poclain, Sakai \& Lokomo. In 1984, Hepco development project was designed in collaboration with Liebherr \& Volvo companies, aiming at fabrication of steel structures of road construction equipment. The capabilities thus gained, was later consolidated in a new Company in 2002 Energy Equipment Production Co. ( Teta ), fully owned by Hepco Today, Hepco, together with its subsidiaries, and in collaboration with its world famous partners is active in production, supply and support of road construction mining and industrial projects .

The main customers of the firm are major manufacturers, which have recently set up programs to streamline the supply processes. Buyers have been requiring adequate logistics performances from their suppliers to reduce inventory, avoid control of orders accuracy and turn the supplying process from a traditional approach to a JIT one. As a consequence, the firm has been asked not only for remarkable products from a technical point of view, but also for remarkable logistics performances, basically in terms of lead time, reliability and accuracy of shipments. Operating in a very competitive scenario from a logistics point of view, the firm needs to proactively manage customer service to retain its customers and gain new market shares. To this extent, the QFD approach proposed in this paper has been recognized by experts in logistics as a valid tool to control logistics performances and promptly tune service delivered to match customer requirements.

\subsection{Results and discussion}

When applying the proposed HOQ to the real case, appropriate "whats" have to be identified. To this extent, four firm main buyers were asked to take part in the application. In the following, they will be indicated as $\mathrm{C}_{1}, \mathrm{C}_{2}, \mathrm{C}_{3}, \mathrm{C}_{4}$. First of all, the importance of each customer has been weighted through the percentage of profit margin generated, as shown in Table 3. 
Table 3

Importance ranking of the firm's main customers

\begin{tabular}{lc}
\hline Customer & Importance judgment \\
\hline $\mathrm{C}_{1}$ & Very high \\
$\mathrm{C}_{2}$ & Very high \\
$\mathrm{C}_{3}$ & High \\
$\mathrm{C}_{4}$ & High \\
\hline
\end{tabular}

The main service factors "whats" to be considered in the real case application have emerged from a preliminary survey phase, which has been performed through direct interviews carried out by academicians with the customers involved in the project. A survey has been adopted because it emerged as one of the most efficient and effective ways to ponder the performance perceived for each factor affecting customer satisfaction (see Keller et al., 2002). The relevant logistics "whats" are shown in Table 4, together with a brief description.

Table 4

Service factors considered in the real case application

\begin{tabular}{ll}
\hline Service factors & Description \\
\hline Lead-time & Time period elapsing from customer's order until receipt \\
Flexibility & Capability to modify orders in terms of due date and quantity when required \\
Accuracy & Avoidance of mistakes and damages in orders delivered. \\
Reliability & Capability to deliver orders within the due date \\
Fill rate & $\begin{array}{l}\text { Common indicator of customer service performance related to inventory. It can be defined as the } \\
\text { percentage of units available when requested by customers. }\end{array}$ \\
Frequency & Number of deliveries accomplished in a given time period. \\
Organization accessibility & Customer's opportunity to establish a contact with firm's staff. \\
Complaints management & $\begin{array}{l}\text { Process subsequent to the recognition of some errors in service provided, that allows service quality } \\
\text { standards to be reestablished. }\end{array}$ \\
\hline
\end{tabular}

The second part of the application focused on the assessment of viable SAs "hows", their mutual correlations, as well as of the relationships judgments between SAs and customer SFs. We agreed to adopt a linguistic approach. In a similar manner, appropriate linguistic scales were set up for the evaluation of relative and weighted importance of SFs, the relative and weighted importance of SAs, the costs for the implementation of SAs, together with values in the relationships and correlations matrixes. Strategic actions "hows" were identified based both on literature analysis and the firm characteristics, whose peculiarities have emerged from group thinking by experts in Hepco copany. Results are shown in Table 5 with a brief description for each point.

\section{Table 5}

Strategic actions considered in HEPCO Company

\begin{tabular}{ll}
\hline Strategic actions & Description \\
\hline Transport management & $\begin{array}{l}\text { Transportation has been recognized as a paramount factor affecting effectiveness and efficiency of logistics } \\
\text { processes. Through transportations, the product value is increased by making it available where and when it } \\
\text { is required. However, transports add significant costs, which could jeopardize the profitability of the supply } \\
\text { chain. }\end{array}$ \\
$\begin{array}{l}\text { JIT helps to smooth the production process through the efficient flow of materials, i.e. by providing the right } \\
\text { materials, in the right quantities and quality, Just-In-Time for production. }\end{array}$ \\
$\begin{array}{l}\text { Information technology is generic term used to include hardware, software and networking technologies, } \\
\text { such as servers, computer networks, expert systems, software for communication, such as Enterprise } \\
\text { Requirement Planning (ERP), Electronic Data Interchange (EDI), etc. } \\
\text { Femand forecasting } \\
\text { Fethods }\end{array}$ \\
$\begin{array}{l}\text { Warehouse } \\
\text { management } \\
\text { optimization }\end{array}$ \\
$\begin{array}{l}\text { Inventory management methods are tools that aim at foreknow customers' demand, in order to reduce its uncertainty. } \\
\text { functional areas of the warehouse, the number and location of docks and input/output (I/O) points, the } \\
\text { number of aisles, etc. }\end{array}$ \\
$\begin{array}{l}\text { Inventory management is a tool that aims at planning and controlling the act of determining and allocating } \\
\text { the products inventory to customers. } \\
\text { Customer relationship } \\
\text { management }\end{array}$ & $\begin{array}{l}\text { CRM is a generic term, which encompasses methodologies, software, and Internet capabilities that help the } \\
\text { firm to manage customer relationships in an organized way. }\end{array}$ \\
\hline
\end{tabular}


During the survey phase, the four customers have also been asked about the importance of service factors, in order to determine the relative importance of service factors, as well as to assess the distance between the service delivered for each factor and the performance that is perceived as superior. The four customers have been asked to rank the relative importance of each SF on a 4-point linguistic rating scale, ranging from VL (Very Low) to VH (Very High). The fuzzy scale is shown in Table 6.

Table 6

Linguistic judgments and corresponding fuzzy numbers

\begin{tabular}{ll}
\hline Judgment & Fuzzy number \\
\hline Very high (VH) & $(0.7 ; 1 ; 1)$ \\
High (H) & $(0.5 ; 0.7 ; 1)$ \\
Low (L) & $(0 ; 0.3 ; 0.5)$ \\
Very low (L) & $(0 ; 0 ; 0.3)$ \\
\hline
\end{tabular}

$\mathrm{W}_{\mathrm{i}, \mathrm{x}}$ is the fuzzy triangular number which is adopted to translate the linguistic importance judgment given to the $i^{\text {th }}$ SF by the $x^{\text {th }}$ customer. $\mathrm{w}_{\mathrm{i}, \mathrm{x}}$ fuzzy numbers have been pooled to determine an aggregate value to be used in the HOQ, that is the relative importance $\mathrm{W}_{\mathrm{i}}$ previously defined. To this extent, the relative importance $\mathrm{W}_{\mathrm{i}}$ of service factor $\mathrm{i}^{\text {th }}$ can be computed as a weighted average of $\mathrm{w}_{\mathrm{i}, \mathrm{x}}$, being weight the importance of customers. The weighted average takes into account the issue that not all customers are equal: being resources limited, the firm should tend to provide best class service for those factors, which are important for key customers. In the specific case, the following equation is applied.

$$
W_{i}=\sum_{x=1}^{4} I_{x} \otimes w_{i, x,} \quad i=1, \ldots, n
$$

where $I_{x}$ is the importance of $x^{\text {th }}$ customer surveyed $(x=1, \ldots, 4)$. Based on values shown in Table 3 , the work group has expressed a fuzzy importance judgment using the same 4-point linguistic scale. The resulting fuzzy numbers have been used in the computation of $\mathrm{W}_{\mathrm{i}}$. Results are shown in Table 7 . As can be seen from the table, the four customers consider lead-time, accuracy and reliability as the most important factors. Once $W_{i}$ were calculated, the weighted importance $\mathrm{W}_{\mathrm{i}}{ }^{*}[\mathrm{n} \times 1]$ of SFs was computed in accordance with Eq. (2). As regards to the crisp distance $d_{i}$ between the firm's performance and the one that is perceived by customer as superior, the parameter has been computed as the average of crisp distances $d_{i, x}$ the generic $\mathrm{x}^{\text {th }}$ customer perceives against $i^{\text {th }}$ service factor, as shown in the following equation:

$$
d_{i}=\frac{\sum_{x=1}^{4} d_{i, x}}{4}, \quad i=1, \ldots, n \text {. }
$$

\section{Table 7}

Fuzzy importance $\mathrm{w}_{\mathrm{i}, \mathrm{x}}$ assigned to service factors by each customer and the relative importance of service

\begin{tabular}{|c|c|c|c|c|c|c|c|c|c|}
\hline \multirow[t]{2}{*}{ Service factors } & \multicolumn{4}{|c|}{ Importance judgment } & \multicolumn{4}{|c|}{ Relative importance $\mathrm{w}_{\mathrm{i}, \mathrm{x}}$} & \multirow{2}{*}{$\begin{array}{l}\text { Relative } \\
\text { Importance of } \\
\text { service factors } \mathrm{w}_{\mathrm{i}}\end{array}$} \\
\hline & $\mathrm{C}_{1}$ & $\mathrm{C}_{2}$ & $\mathrm{C}_{3}$ & $\mathrm{C}_{4}$ & $\mathrm{C}_{1}$ & $\mathrm{C}_{2}$ & $\mathrm{C}_{3}$ & $\mathrm{C}_{4}$ & \\
\hline Lead-time & VH & $\mathrm{VH}$ & $\mathrm{VH}$ & VH & $(0.7,1,1)$ & $(0.7,1,1)$ & $(0.7,1,1)$ & $(0.7,1,1)$ & $(1.68,3.4,4)$ \\
\hline Flexibility & VH & $\mathrm{H}$ & $\mathrm{H}$ & $\mathrm{L}$ & $(0.7,1,1)$ & $(0.5,0.7,1)$ & $(0.5,0.7,1)$ & $(0,0.3,0.5)$ & $(1.09,2.4,3.5)$ \\
\hline Accuracy & VH & $\mathrm{VH}$ & $\mathrm{VH}$ & $\mathrm{VH}$ & $(0.7,1,1)$ & $(0.7,1,1)$ & $(0.7,1,1)$ & $(0.7,1,1)$ & $(1.68,3.4,4)$ \\
\hline Reliability & VH & VH & VH & $\mathrm{VH}$ & $(0.7,1,1)$ & $(0.7,1,1)$ & $(0.7,1,1)$ & $(0.7,1,1)$ & $(1.103,3.4,4)$ \\
\hline Frequency & VH & $\mathrm{H}$ & $\mathrm{H}$ & $\mathrm{H}$ & $(0.7,1,1)$ & $(0.5,0.7,1)$ & $(0.5,0.7,1)$ & $(0.5,0.7,1)$ & $(1.34,2.68,4)$ \\
\hline Fill rate & VH & $\mathrm{VH}$ & $\mathrm{H}$ & VH & $(0.7,1,1)$ & $(0.7,1,1)$ & $(0.5,0.7,1)$ & $(0.7,1,1)$ & $(1.58,3.19,4)$ \\
\hline $\begin{array}{l}\text { Organization } \\
\text { accessibility }\end{array}$ & VH & VH & $\mathrm{H}$ & $\mathrm{VH}$ & $(0.7,1,1)$ & $(0.7,1,1)$ & $(0.5,0.7,1)$ & $(0.7,1,1)$ & $(1.58,3.19,4)$ \\
\hline $\begin{array}{l}\text { Complaints } \\
\text { management }\end{array}$ & $\mathrm{VH}$ & $\mathrm{L}$ & $\mathrm{H}$ & $\mathrm{H}$ & $(0.7,1,1)$ & $(0,0.3,0.5)$ & $(0.5,0.7,1)$ & $(0.5,0.7,1)$ & $(0.99,2.28,3.5)$ \\
\hline
\end{tabular}
factors $\mathrm{W}_{\mathrm{i}}$ 
Parameters $d_{i, x}$ have been obtained basing on the survey results and by applying Eq. (1). To this extent, a section of the survey was dedicated to performance judgments about the service delivered by the firm to its customers. The customers were asked to judge the service level they were receiving for each service factor, using the linguistic scale shown in Table 6. Moreover, for each SF, the customers had to indicate the judgment which best matched their perception of a superior service. $d_{i, x}$ parameters as they result from the survey, $\mathrm{d}_{\mathrm{i}}$ values, and the corresponding weighted importance $\mathrm{W}_{\mathrm{i}}{ }^{*}$ are shown in Table 8 and Table 9.

\section{Table 8}

Distances $\mathrm{d}_{i}$ from the optimum performance and weighted importance $\mathrm{Wi}^{*}$ of each service factor

\begin{tabular}{|c|c|c|c|c|c|c|c|c|c|c|c|c|}
\hline & \multicolumn{4}{|c|}{ Performance judgments } & \multicolumn{4}{|c|}{ Optimum performance } & \multicolumn{4}{|c|}{ Distance di, $\mathrm{x}$} \\
\hline & $\mathrm{C}_{1}$ & $\mathrm{C}_{2}$ & $\mathrm{C}_{3}$ & $\mathrm{C}_{4}$ & $\mathrm{C}_{1}$ & $\mathrm{C}_{2}$ & $\mathrm{C}_{3}$ & $\mathrm{C}_{4}$ & $\mathrm{C}_{1}$ & $\mathrm{C}_{2}$ & $\mathrm{C}_{3}$ & $\mathrm{C}_{4}$ \\
\hline Lead-time & $\mathrm{H}$ & $\mathrm{L}$ & $\mathrm{L}$ & $\mathrm{L}$ & VH & $\mathrm{VH}$ & $\mathrm{VH}$ & $\mathrm{VH}$ & 0.1 & 0.6 & 0.6 & 0.6 \\
\hline Flexibility & $\mathrm{H}$ & $\mathrm{L}$ & $\mathrm{L}$ & $\mathrm{L}$ & VH & $\mathrm{H}$ & VH & VH & 0.1 & 0.5 & 0.6 & 0.6 \\
\hline Accuracy & $\mathrm{H}$ & $\mathrm{H}$ & $\mathrm{H}$ & $\mathrm{H}$ & $\mathrm{VH}$ & $\mathrm{VH}$ & $\mathrm{H}$ & $\mathrm{VH}$ & 0.1 & 0.1 & 0 & 0.1 \\
\hline Reliability & $\mathrm{L}$ & $\mathrm{L}$ & $\mathrm{L}$ & $\mathrm{H}$ & VH & VH & VH & VH & 0.6 & 0.6 & 0.6 & 0.1 \\
\hline Frequency & $\mathrm{H}$ & $\mathrm{L}$ & $\mathrm{L}$ & $\mathrm{L}$ & VH & VH & VH & VH & 0.1 & 0.6 & 0.6 & 0.6 \\
\hline Fill rate & L & $\mathrm{H}$ & $\mathrm{L}$ & $\mathrm{L}$ & $\mathrm{VH}$ & $\mathrm{VH}$ & $\mathrm{VH}$ & VH & 0.6 & 0.1 & 0.6 & 0.6 \\
\hline $\begin{array}{l}\text { Organization } \\
\text { accessibility }\end{array}$ & VH & $\mathrm{VH}$ & $\mathrm{H}$ & $\mathrm{H}$ & VH & $\mathrm{VH}$ & $\mathrm{H}$ & $\mathrm{H}$ & 0 & 0 & 0 & 0 \\
\hline $\begin{array}{l}\text { Complaints } \\
\text { management }\end{array}$ & $\mathrm{H}$ & $\mathrm{H}$ & $\mathrm{L}$ & $\mathrm{H}$ & VH & VH & $\mathrm{H}$ & $\mathrm{H}$ & 0.1 & 0.1 & 0.5 & 0 \\
\hline
\end{tabular}

Table 9

Weighted importance $\mathrm{W}_{\mathrm{i}}{ }^{*}$ of each service factor

\begin{tabular}{|c|c|c|c|}
\hline & Distance di & Relative importance Wi & Weighted importance Wi* \\
\hline Lead-time & 0.475 & $(1.68,3.4,4)$ & $(0.798,1.615,1.9)$ \\
\hline Flexibility & 0.45 & $(1.09,2.4,3.5)$ & $(0.491,1.08,1.575)$ \\
\hline Accuracy & 0.075 & $(1.68,3.4,4)$ & $(0.126,0.255,0.3)$ \\
\hline Reliability & 0.475 & $(1.103,3.4,4)$ & $(0.524,1.615,1.9)$ \\
\hline Frequency & 0.475 & $(1.34,2.68,4)$ & $(0.637,1.273,1.9)$ \\
\hline Fill rate & 0.475 & $(1.58,3.19,4)$ & $(0.751,1.515,1.9)$ \\
\hline Organization accessibility & 0 & $(1.58,3.19,4)$ & $(0,0,0)$ \\
\hline Complaints management & 0.175 & $(0.99,2.28,3.5)$ & $(0.173,0.399,0.613)$ \\
\hline
\end{tabular}

From outcomes analysis, it emerges that customers perceive a significant difference between the firm's service performance and optimum one in terms of lead-time, accuracy, reliability, frequency \& fill rate. Considering crisp values gained for $\mathrm{W}_{\mathrm{i}}{ }^{*}$, we found that lead-time factor has the highest priority in customer's opinion, and organization accessibility has the lowest priority. The next step in the construction of the HOQ was the assessment of the relationships matrix $R_{i j}[n \times m]$. To this extent, strategic actions SAs for customer satisfaction have been listed in columns, while service factors SFs have been crossed over in rows. The degree of relationship (weak, medium, strong) between SAs and SFs has been expressed with linguistic judgments. Since fuzzy logic is exploited to well cope with the ill-defined nature of linguistics judgements, these judgments have been translated to corresponding fuzzy numbers according to Table 10 .

\section{Table 10}

Degree of relationship, graphic symbols and corresponding fuzzy numbers

\begin{tabular}{ll}
\hline Degree of relationship & Fuzzy number \\
\hline Strong & $(0.7 ; 1 ; 1)$ \\
Medium & $(0.3 ; 0.5 ; 0.7)$ \\
Weak & $(0 ; 0 ; 0.3)$ \\
\hline
\end{tabular}

During this phase, we benefited from a preliminary literature survey phase, which strived to highlight the relationships between service factors and strategic actions. The resulting relationships matrix is shown in the center of Table 12. The roof of correlations was built up in a similar manner. Again, linguistic judgments have been used to express the correlations between strategic actions (strong negative, negative, positive, strong positive) then they have been translated into fuzzy triangular numbers, as shown in Table 11. 
Table 11

Degree of correlation, graphic symbols and corresponding fuzzy numbers

\begin{tabular}{ll}
\hline Degree of correlation & Fuzzy number \\
\hline Strong positive & $(0.7 ; 1 ; 1)$ \\
Positive & $(0.5 ; 0.7 ; 1)$ \\
Negative & $(0 ; 0.3 ; 0.5)$ \\
Strong negative & $(0 ; 0 ; 0.3)$ \\
\hline
\end{tabular}

Once the relationships matrix and the roof of correlations were compiled, the relative importance $\mathrm{RI}_{\mathrm{j}}$ and the weighted importance $\mathrm{RI}_{\mathrm{j}}{ }^{*}$ of each strategic action were computed in accordance with Eq. (3) and Eq. (4) respectively. Results are shown in Table 12. Then, the cost $C_{j}$ for the implementation of each strategic action was determined to evaluate the marginal benefit $U_{j}$. To this extent, experts were asked to express a linguistic judgment about the investment required for each strategic action, by using the same 4 value fuzzy scale previously shown in Table 6 . Results are shown in Table 12 . It should be remarked that fuzzy logic was found to be a very consistent and easy to use tool to handle such a vague, imprecise and ill-defined issue as costs estimation for strategic actions. Then, the fuzzy resulting benefits $U_{j}$ have been computed according to Eq. (5). Finally, fuzzy $U_{j}$ parameters were defuzzified applying Eq. (8). Crisp $\mathrm{U}_{\mathrm{j}}$ obtained can be regarded as synthesis parameters, expressing the overall efficiency of implementing the jth strategic action. The final ranking of strategic actions together with the fuzzy and crisp $U_{j}$ values are shown in the last two rows of Table 12 .

As a result, JIT implementation emerged as the strategic action with the highest implementation priority, since it makes it possible to improve most of service factors: lead time, flexibility, reliability, frequency and fill-rate. Also JIT has been proved to have positive correlations against other strategic actions. Finally, we can rank strategic actions as follows:

JIT implementation, inventory management, demand forecasting methods, customer relationship management, warehouse lay-out optimization, information technology, and transport management.

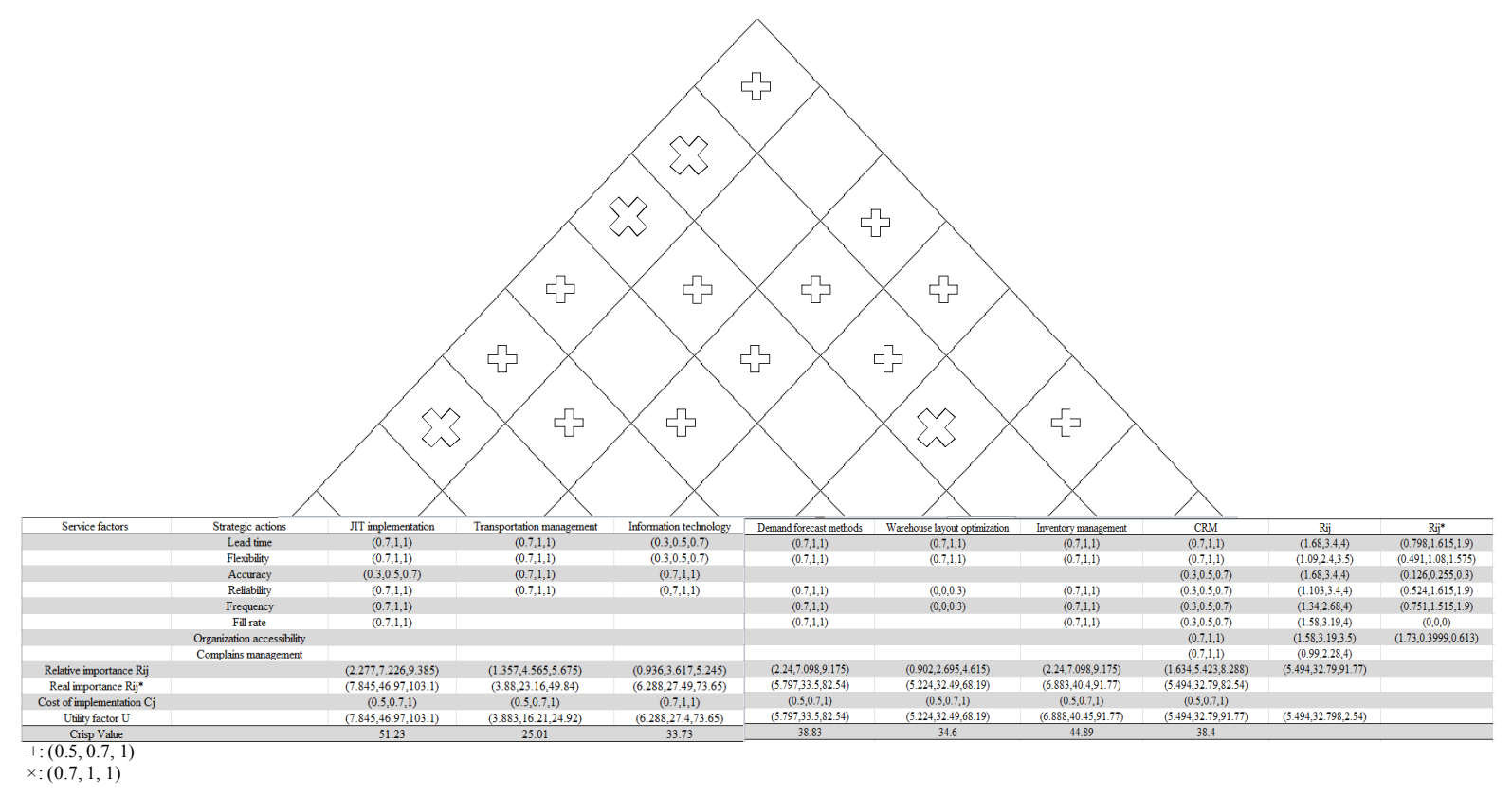

\section{Conclusion}

This paper has discussed the way of strategic management of logistics services and processes for a big manufacturer. It has proposed an approach based on the quality function deployment (QFD), for 
ranking strategic actions to improve logistics service. The paper has addressed the issue of how to deploy the house of quality (HOQ) to effectively and efficiently improve logistics processes and thus customer satisfaction. For data collection, fuzzy logic has been used to deal with the ill-defined nature of the qualitative linguistic judgments required in the proposed HOQ. The methodology has been tested by means of a real case application, which refers to an Iranian company operating in the manufacturing industry.

The approach proposed could be considered as a useful tool for selecting the most efficient and effective logistics leverages to reach customer satisfaction. In particular, the methodology allows the identification of the service factors that are perceived to affect logistics performances from the customer's point of view, enabling the assessment of possible gaps between customers' and firm's perception of logistics service. As a matter of fact, this is why firm's perception should not be considered as the starting point in developing service strategies, while direct interviews with customers are required. In order to assess and rank viable strategic actions, in the approach proposed we have introduced a utility factor, which considers the costs of implementation for each "how". The utility factor can be directly adopted as a synthesis parameter to select the most suitable strategic action to implement. Ultimately, the strategic actions have been ranked as follows:

1)JIT implementation, 2)Inventory management, 3) Demand forecasting methods, 4) Customer relationship management, 5)Warehouse lay-out optimization, 6)Information technology, and 7)Transport management.

As we can see, JIT implementation has the highest priority, and it can be the result of strong relationship between JIT and the most important service factors. After JIT implementation, inventory management and demand forecasting method has the highest priority. It could be the result of strong relationship between these two strategic actions and fill-rate.

Although information technology has a strong effect on service improvement, its priority is low, because according to HEPCO's experts, organization needs high budget for implementing information technology. Therefore, if top management of the company plan to implement strategic actions according to the results above, can access customer satisfaction, higher market share and more benefit.

\section{References}

Akao, Y. (1990). Quality Function Deployment: Integrating Customer Requirements into Product Design. The Productivity Press, Cambridge, MA.

Baines, A. (1996). Designing customer service programmes. Work study, 45(1), 20-23.

Behara, R.S., \& Chase, R.B. (1993). Service quality deployment: Service quality by design. In: Sarin, R.V. (Ed.), Perspectives in Operations Management: Essays in Honor of Elwood S. Buffa. Kluwer Academic Publisher, Norwell, MA.

Bossert, J. L. (1991). Quality function deployment-A practitioner's approach. NY: ASQC Quality Press.

Bottani, E., \& Rizzi, A. (2006). Strategic management of logistics service: A fuzzy QFD approach. International Journal of Production Economics, 103, 585-599.

Byrne P.M., \& Markham W.J. (1991). Improving quality and productivity in the logistics process Achieving customer satisfaction breakthroughs. Council of Logistics Management, Oak Brook, IL.

Carothers, G. H., \& Adams, M. (1991). Competitive advantage through customer value: the role of value-based strategies. Competing globally through customer value, 32-66. 
Celik, M., Kahraman, C., Cebi, S., \& Er, I. D. (2009). Fuzzy axiomatic design-based performance evaluation model for docking facilities in shipbuilding industry: The case of Turkish Shipyards. Expert Systems with Applications, 36(1), 599-615.

Chan, L. K., Kao, H. P., \& Wu, M. L. (1999). Rating the importance of customer needs in quality function deployment by fuzzy and entropy methods. International Journal of Production Research, 37(11), 2499-2518.

Chase, R. B., \& Garvin, D. A. (1989). The service factory. Harvard Business Review 67(4), 61-69.

Chen, Y., Fung, R. Y., \& Tang, J. (2006). Rating technical attributes in fuzzy QFD by integrating fuzzy weighted average method and fuzzy expected value operator. European Journal of Operational Research, 174(3), 1553-1566.

Chien, C. J., \& Tsai, H. H. (2000). Using fuzzy numbers to evaluate perceived service quality. Fuzzy sets and systems, 116(2), 289-300.

Choen, L. (1995). Quality Function Deployment: How to Make QFD Work for You. Addison-Wesley Publishing Company, Reading, MA.

Christopher, M. (1983). Creating effective policies for customer service.International Journal of Physical Distribution \& Logistics Management, 13(2), 3-24.

Cooper M.C., LaLonde B.J., Noordewier T.G. (1988). Customer Service: A Management Perspective. Council of Logistics Management, USA.

DeRoulet, D. G. (1992). Designing--and sustaining the gains from--a service strategy. The Journal of business strategy, 14(1), 21-30.

Fuller, J. B., O'Conor, J., \& Rawlinson, R. (1993). Tailored logistics: the next advantage. Harvard Business Review, 71(3), 87-98.

Hauser J.R., Clausing D. (1988). The house of quality. Harvard Business Rev. 63-73.

Kahraman, C., Ertay, T., \& Büyüközkan, G. (2006). A fuzzy optimization model for QFD planning process using analytic network approach. European Journal of Operational Research,171(2), 390-411.

Keller, S.B., Savitskie, K., Stank, T.P., Lynch, D.F., \& Ellinger, A.E. (2002). A summary and analysis of multi-item scales used in logistics research. Journal of Business Logistics, 23(2), 83281.

Khoo, L. P., \& Ho, N. C. (1996). Framework of a fuzzy quality function deployment system. International Journal of Production Research, 34(2), 299-311.

Korpela J., Tuominen M. (1997). Group decision support for analysing logistics development projects, in: The Proceedings of the 30th Hawaii International Conference on System Sciences, vol. II, IEEE Computer Society, Los Alamitos, CA, 1997, pp. 493-502.

Kwong, C. K., Chen, Y., Bai, H., \& Chan, D. S. K. (2007). A methodology of determining aggregated importance of engineering characteristics in QFD. Computers \& Industrial Engineering, 53(4), 667-679.

LaLonde B.J., \& Zinszer P.H. (1976). Customer Service: Meaning and Measurement. National Council of Physical Distribution Management, USA.

Lambert, D. M., \& Harrington, T. C. (1989). Establishing customer service strategies within the marketing mix: more empirical evidence. Journal of Business Logistics, 10(2). 44-59.

Lambert D.M., \& Stock J.R. (1993). Strategic Logistics Management. $3^{\text {rd }}$ ed. Richard D. Irwin, Homewood, IL.

Langley Jr. C.J., \& Holcomb M.C. (1992). Creating logistics customer value. Journal of Business Logistics, 13(2), 1-27.

Lapidus, R. S., \& Schibrowsky, J. A. (1994). Aggregate complaint analysis: a procedure for developing customer service satisfaction. Journal of Services Marketing, 8(4), 50-60.

Livingstone, G. (1992). Measuring customer service in distribution. International Journal of Physical Distribution and Logistics Management, 22(6), 4-6.

Manrodt K.B., \& Davis Jr. F.W. (1992). The evolution to service response logistics. International Journal of Physical Distribution and Logistics Management, 22(9), 3-10. 
Mentzer J. T., Games, R., \& Krapfel, R. E. Jr. (1989) Physical distribution service: a fundamental marketing concept. Journal of the Academy of Marketing Science, 17(1), 5362.

Morris, J. (1996). Leading to customer care. Industrial and Commercial Training, 28(5), 7-10.

O’Neil B.F., \& Iveson J.L. (1991). An operational procedure for prioritizing customer service elements. Journal of Business Logistics, 12 (2), 157-191.

Pirttilä, T., \& Huiskonen, J. (1996). A framework for cost-service analysis in differentiation of logistics services. International journal of production economics, 45(1), 131-137.

ReVelle, J. B., Moran, J. W., \& Cox, C. A. (1998). The QFD handbook, John Wiley \& Sons. New York.

Schary P.B. (1992). A concept of customer service. Logistics and Transportation Review, 28(4), 341352.

Semeijn, J. (1995). Service priorities in international logistics. International Journal of Logistics Management, The, 6(1), 27-36.

Sharma, A., \& Lambert, D. M. (1991). Using salespeople to collect customer service information. International Journal of Physical Distribution \& Logistics Management, 21(6), 2731.

Shen, X. X., Xie, M., \& Tan, K. C. (2001). Listening to the future voice of the customer using fuzzy trend analysis in QFD. Quality Engineering, 13(3), 419-425.

Shen, X. X., Tan, K. C., \& Xie, M. (2001). The implementation of quality function deployment based on linguistic data. Journal of Intelligent Manufacturing, 12(1), 65-75.

Shycon, H. N. (1992). Improved customer service: measuring the payoff. The Journal of Business Strategy, 13-17.

Sohn Y.S., \& Choi I.S. (2001). Fuzzy QFD for supply chain management with reliability, Reliability Engineering and System Safety, 72, 327-334.

Sterling, J. U., \& Lambert, D. M. (1987). Establishing customer service strategies within the marketing mix. Journal of business Logistics, 8(1). 1-23.

Stern, L. W., Sturdivant, F. D., \& Getz, G. A. (1993). Accomplishing marketing channel change: Paths and pitfalls. European Management Journal, 11(1), 1-8.

Stuart, F.I., \& Tax, S.S. (1996). Planning for service quality: An integrative approach. International Journal of Service Industry Management, 7(4), 58-77.

Trappey, C.V., Trappey, A.J.C., \& Hwang, S.J. (1996). A computerized quality function deployment approach for retail services. Computers and Industrial Engineering, 30 (4), 611-622.

VanHuss S.H. (1993). Effective customer service. $B \&$ E Review, 21-25.

Yager, R.R. (1981). A procedure for ordering fuzzy subsets of the unit interval. Information Science, 24, 143-161.

Zadeh, L.A. (1965). Fuzzy sets. Information and Control, 8, 338-353.

Zimmermann, H.J. (1991). Fuzzy Set Theory and its Applications. $2^{\text {nd }}$ ed. Kluwer Academic Publishers, Boston. 